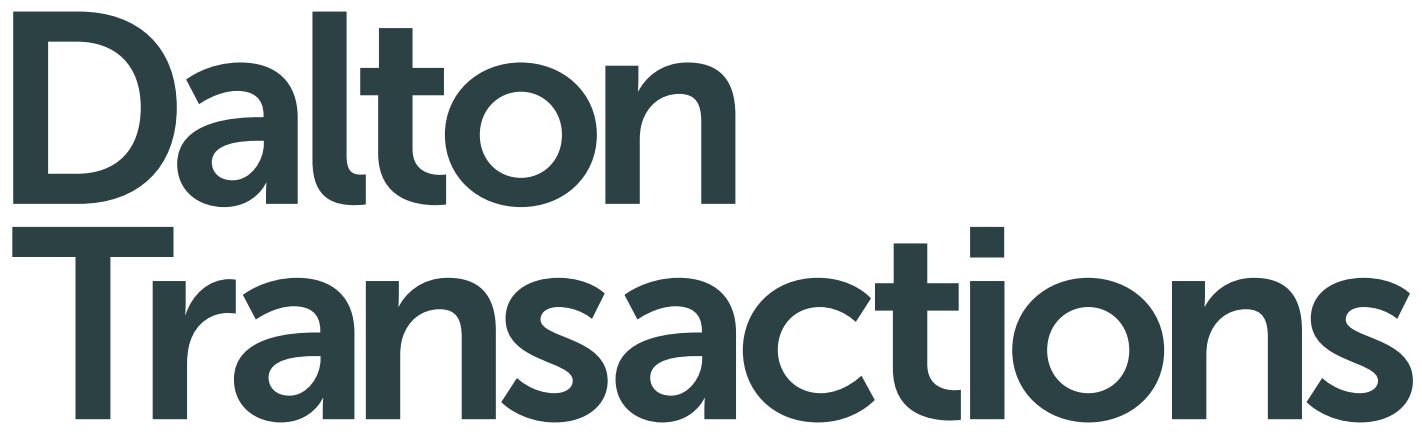

An international journal of inorganic chemistry www.rsc.org/dalton

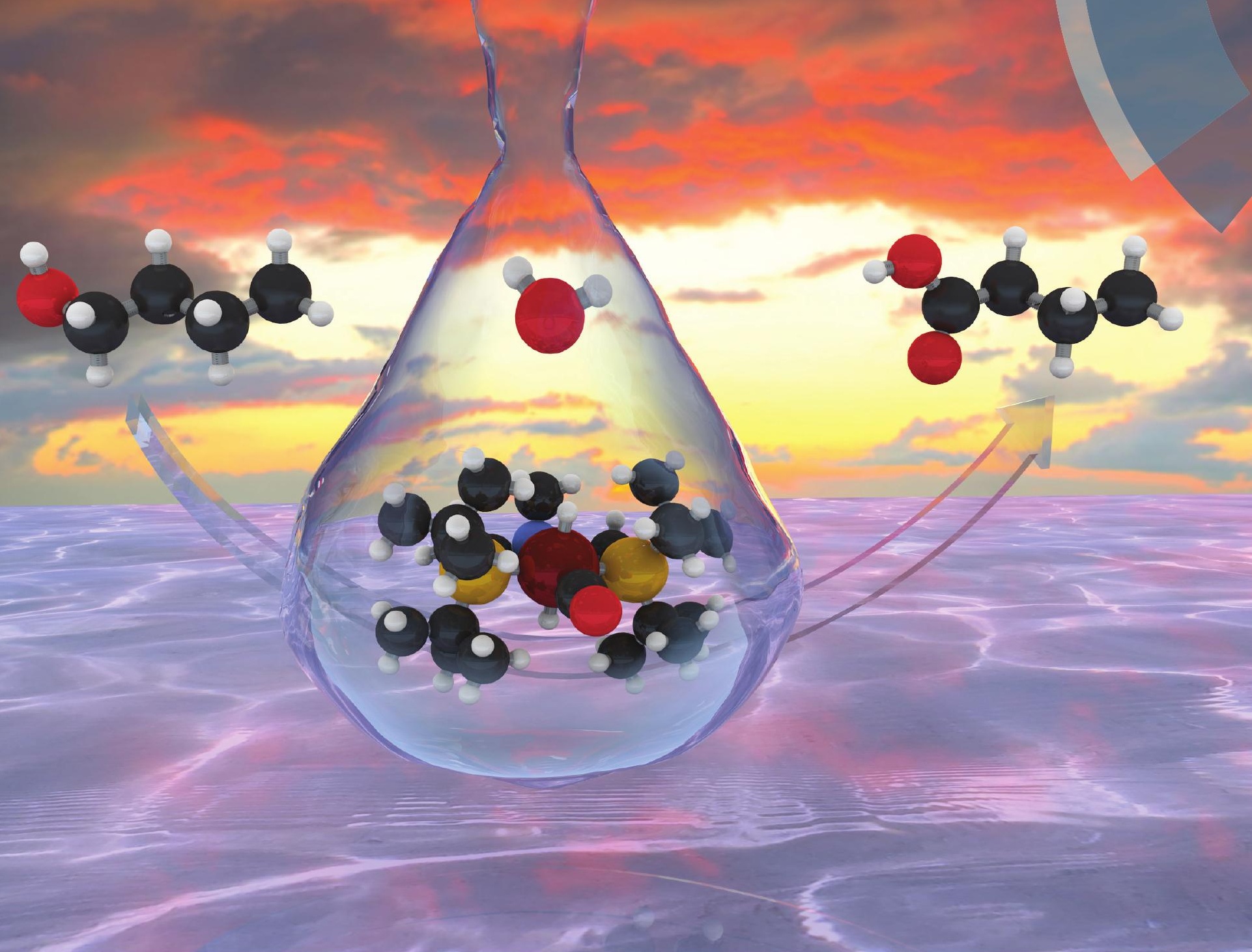

ISSN 1477-9226 


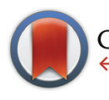

CrossMark \& click for updates

Cite this: Dalton Trans., 2014, 43 17248

Received 3rd June 2014,

Accepted 27th June 2014

DOI: $10.1039 / c 4 d t 01634 c$

www.rsc.org/dalton

\title{
Selective conversion of alcohols in water to carboxylic acids by in situ generated ruthenium trans dihydrido carbonyl PNP complexes $\uparrow$
}

\author{
Jong-Hoo Choi, ${ }^{a}$ Leo E. Heim, ${ }^{a}$ Mike Ahrens ${ }^{b}$ and Martin H. G. Prechtl ${ }^{* a}$ \\ In this work, we present a mild method for direct conversion of primary alcohols into carboxylic acids \\ with the use of water as an oxygen source. Applying a ruthenium dihydrogen based dehydrogenation \\ catalyst for this cause, we investigated the effect of water on the catalytic dehydrogenation process of \\ alcohols. Using $1 \mathrm{~mol} \%$ of the catalyst we report up to high yields. Moreover, we isolated key intermediates \\ which most likely play a role in the catalytic cycle. One of the intermediates was identified as a trans di- \\ hydrido carbonyl complex which is generated in situ in the catalytic process.
}

\section{Introduction}

Catalytic oxidation of alcohols is an essential industrial and natural process and leads to important intermediates or products such as aldehydes, ketones or carboxylic acids. Established methods usually require strong and toxic oxidants such as chromium or manganese oxides along with many additives. ${ }^{1-4}$ In some cases, the use of stoichiometric oxygen supplying reactants or even the presence of pure pressurized oxygen is required. ${ }^{5}$ In terms of synthesis of carboxylic acids, mostly the oxidation of aldehydes as the intermediates or starting materials is needed. ${ }^{6}$ The methods of direct oxidation of alcohols to carboxylic acids are still underdeveloped and do not meet today's requirements of a clean and efficient pathway without the need for aggressive and toxic oxidants and avoiding chemical waste products. Despite these disadvantages, only a small number of direct alcohol conversions into carboxylic acids have been reported. ${ }^{7}$ For example, Stark et al. reported a direct oxidation method of alcohols involving tetra$n$-propylammonium perruthenate (TPAP) in the presence of $\mathrm{N}$-methylmorpholine $\mathrm{N}$-oxide (NMO) as a key additive to stabilise the aldehyde hydrate intermediate. ${ }^{8} \mathrm{~A}$ different way was obtained by the Grützmacher group; they reported a homogeneous catalytic transformation of alcohols to acids with high yields under very mild conditions applying a rhodium based

\footnotetext{
${ }^{a}$ Department of Chemistry, University of Cologne, Greinstr. 6, 50939 Cologne, Germany.E-mail: martin.prechtl@uni-koeln.de; http://www.catalysislab.de; Fax: +49221470 1788; Tel: +492214701981

${ }^{b}$ Institute of Chemistry, Humboldt University at Berlin, Brook-Taylor-Straße 2, D-12489 Berlin, Germany

$\dagger$ Electronic supplementary information (ESI) available. CCDC 1002031. For ESI and crystallographic data in CIF or other electronic format see DOI: 10.1039/ c4dt01634c
}

catalyst with cyclohexanone as a hydrogen acceptor. ${ }^{9,10}$ With this similar concept, they also succeeded in converting alcohols into esters or amides. The latest method was reported by the Milstein group in 2013 by applying a bipyridine based PNN ruthenium carbonyl hydride catalyst $\mathbf{1}$ using only water as an oxygen source with no further additives (Fig. 1). ${ }^{11}$ Usually those pincer type ruthenium complexes bearing cooperative (and hemi-labile) pincer-backbones are known for dehydrogenative coupling of alcohols into esters and their reverse hydrogenation reactions into alcohols, and also for N-alkylation reactions from alcohols and amines. ${ }^{12-15}$ In the presence of water, catalyst $\mathbf{1}$ is highly active for catalytic conversion of different alcohols into their corresponding carboxylic acid salts.

Other studies on alcohol dehydrogenation in aqueous solution at low temperature, in particular methanol ${ }^{16-18}$ and methanediol, ${ }^{19}$ also showed the possibility of acceptorless dehydrogenation. In these certain cases the dehydrogenation resulted in the formation of carbon dioxide and hydrogen gas.

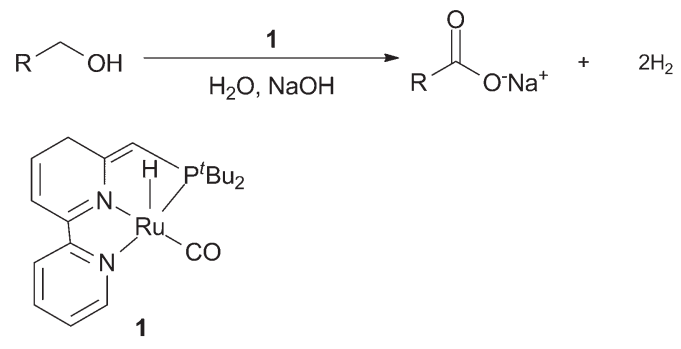

Fig. 1 Direct oxidation of alcohols using a bipyridine ruthenium catalyst $1^{11}$ 


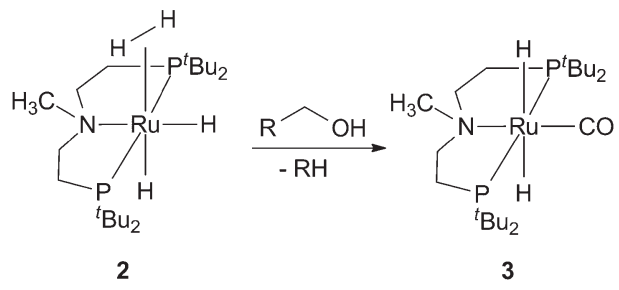

alcohol oxidation
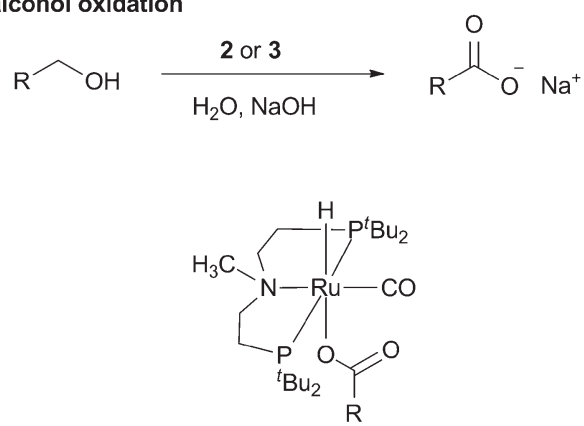

$4 a-b$

4a: $R=$ pentyl

4b: $R=$ methyl

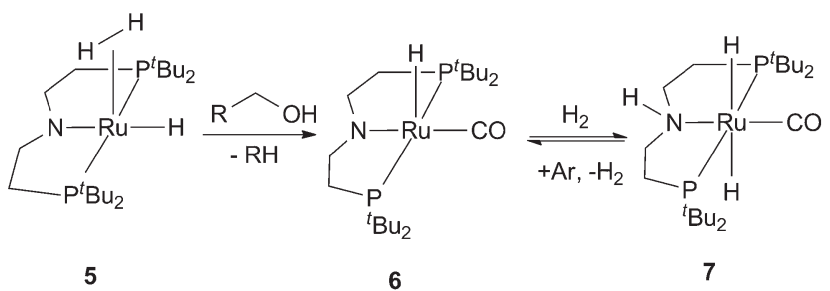

Fig. 2 Ruthenium hydride $\left[\mathrm{Ru}\left(\mathrm{H}_{2}\right) \mathrm{H}_{2}(\mathrm{Me}-\mathrm{PNP})\right] 2$ and trans dihydrido carbonyl complex $\left[\mathrm{RuH}_{2}(\mathrm{CO})(\mathrm{Me}-\mathrm{PNP})\right] 3$ for alcohol oxidation, complex intermediates $4 a-b,\left[R u\left(H_{2}\right) H(P N P)\right] 5$ and carbonyl complexes [RuH (CO)(PNP)] 6 and $\left.\mathrm{RuH}_{2}(\mathrm{CO})(\mathrm{H}-\mathrm{PNP})\right] 7$.

Inspired by the latest achievements, we present a setup using ruthenium PNP pincer complexes $\left[\mathrm{Ru}\left(\mathrm{H}_{2}\right) \mathrm{H}_{2}(\mathrm{Me}-\mathrm{PNP})\right]$ $2^{20}$ and $\left[\mathrm{RuH}_{2}(\mathrm{CO})(\mathrm{Me}-\mathrm{PNP})\right] 3$ for catalytic dehydrogenation of primary alcohols in the presence of water, respectively in the absence of any other oxidants (Fig. 2). Our reactions were conducted with aq. $\mathrm{NaOH}$ solution as the only additive to obtain the carboxylic acid salts in up to high yields. Furthermore, we isolated complex intermediates $\mathbf{3}$ and $\mathbf{4 a - b}$ separately and from the catalytic process (Fig. 2). In our system, complex 2 serves as a precursor which converts in situ via alcohol decarbonylation reaction into a trans dihydrido complex $\left[\mathrm{RuH}_{2}(\mathrm{CO})(\mathrm{Me}-\mathrm{PNP})\right]$ 3. Separately, complex 3 was used for catalytic alcohol dehydrogenation reactions in water. Based on achievements in earlier reports, ${ }^{12,13,21-25}$ we investigated the decarbonylation behaviour of a similar PNP pincer based ruthenium complex $\left[\mathrm{Ru}\left(\mathrm{H}_{2}\right) \mathrm{H}(\mathrm{PNP})\right] \mathbf{5}$. Complex 5 can be transformed into a carbonyl complex $[\mathrm{RuH}(\mathrm{CO})(\mathrm{PNP})] \mathbf{6}$ and converted into a trans dihydride complex $\left[\mathrm{RuH}_{2}(\mathrm{CO})(\mathrm{H}-\mathrm{PNP})\right] 7$ under a hydrogen atmosphere (Fig. 2). Those complexes are important intermediates for different transformations reported by others. ${ }^{26,27}$

\section{Results and discussion}

\section{Catalytic oxidation of alcohols}

For the standard catalytic procedure, a mixture of $2 \mathrm{~mL}$ water, $5 \mathrm{mmol}$ of alcohol, $5.5 \mathrm{mmol}$ of $\mathrm{NaOH}$ and $1.0 \mathrm{~mol} \%$ of $\left[\mathrm{Ru}\left(\mathrm{H}_{2}\right) \mathrm{H}_{2}(\mathrm{Me}-\mathrm{PNP})\right] 2$ or $\left[\mathrm{RuH}_{2}(\mathrm{CO})(\mathrm{Me}-\mathrm{PNP})\right] 3$ was refluxed under continuous argon flow in an open system for $20 \mathrm{~h}$ at $120^{\circ} \mathrm{C}$. The addition of a base $(\mathrm{NaOH})$ is necessary to obtain the carboxylic acid salt and to shift the reaction equilibrium towards the product. After the reaction time, the predominant single aqueous phase was treated with diethyl ether to extract the catalyst. The aqueous layer was then acidified to convert the carboxylic acid salt into its corresponding carboxylic acid which was subsequently extracted with ethyl acetate. Isolated yields of the carboxylic acids are presented in Table 1. In this catalytic oxidation of alcohols we tested a series of aliphatic alcohols along with benzyl alcohol. Best results using catalyst 2 were obtained with hexanol and pentanol yielding 88 and $71 \%$ (entries 1 and 2), while butanol gave a moderate yield of $63 \%$ (entry 3). Catalysing longer aliphatic chained alcohols (entries 4 and 5), the isolated yields dropped down to $33 \%$. This is probably due to a lack of miscibility of these less polar long-chain aliphatic alcohols with water. Benzyl alcohol and cyclohexyl methanol gave yields between 59 and 65\% (entries 6 and 7). After the reaction and extracting the complex with diethyl ether, the organic phase contained only traces of unreacted alcohol, but no ester as a by-product. A slight increase of the yields was obtained with complex 3 . The reaction of hexanol to hexanoic acid gave similar yields (entries 1 and 8); for butanol and pentanol (entries 9 and 10) an increase of around $10 \%$ was obtained. Isolated yields for octanol and decanol (entries 11 and 12) remained unchanged. The oxidation of benzyl alcohol to benzoic acid improved from $65 \%$ yield to $85 \%$ (entry 13 ). In contrast, the conversion of cyclohexyl methanol dropped to 36\%. With complexes 5 and 6 the

Table 1 Dehydrogenation of alcohols in the presence of water

\begin{tabular}{lllll}
\hline Entry $^{a}$ & Cat. & Alcohol & Product & Yield \\
\hline 1 & 2 & Hexanol & Hexanoic acid & 88 \\
2 & 2 & Pentanol & Valeric acid & 71 \\
3 & 2 & Butanol & Butyric acid & 63 \\
4 & 2 & Octanol & Caprylic acid & 42 \\
5 & 2 & Decanol & Decanoic acid & 33 \\
6 & 2 & Benzyl alcohol & Benzoic acid & 65 \\
7 & 2 & Cyclohexyl methanol & Cyclohexyl carboxylic acid & 59 \\
8 & 3 & Hexanol & Hexanoic acid & 92 \\
9 & 3 & Pentanol & Valeric acid & 83 \\
10 & 3 & Butanol & Butyric acid & 73 \\
11 & 3 & Octanol & Caprylic acid & 45 \\
12 & 3 & Decanol & Decanoic acid & 32 \\
13 & 3 & Benzyl alcohol & Benzoic acid & 85 \\
14 & 3 & Cyclohexyl methanol & Cyclohexyl carboxylic acid & 36 \\
15 & $\mathbf{5}$ & Hexanol & Hexanoic acid & 53 \\
16 & $\mathbf{6}$ & Hexanol & Hexanoic acid & 61
\end{tabular}

${ }^{a}$ Reaction at $120{ }^{\circ} \mathrm{C}, 20 \mathrm{~h}$ with $1 \mathrm{~mol} \%$ cat. $2,3,5$ or $6,5 \mathrm{mmol}$ alcohol, $5.5 \mathrm{mmol} \mathrm{NaOH}$. 
yields for the hexanol oxidation were 53\% and 61\% (entries 15 and 16).

\section{Formation of the active species and characterisation of the isolated complex intermediates}

At the beginning of the catalysis, the trans dihydrido carbonyl complex $\left[\mathrm{RuH}_{2}(\mathrm{CO})(\mathrm{Me}-\mathrm{PNP})\right] \mathbf{3}$ is formed through decarbonylation of the primary alcohol by $\left[\mathrm{Ru}\left(\mathrm{H}_{2}\right) \mathrm{H}_{2}(\mathrm{Me}-\mathrm{PNP})\right] 2$ (Scheme 1). Separately in another experiment, complex 3 was obtained by adding 3.5 equivalents of ethyl, pentyl or hexyl alcohols to $\left[\mathrm{Ru}\left(\mathrm{H}_{2}\right) \mathrm{H}_{2}(\mathrm{Me}-\mathrm{PNP})\right] 2$ in a closed system at $80{ }^{\circ} \mathrm{C}$ for $48 \mathrm{~h}$, with very good yields, which is stable under an argon atmosphere at room temperature. Furthermore, a series of gas phase mass spectra were recorded to detect the fragmentations of the evolved aliphatic hydrocarbons from the decarbonylation reactions of the corresponding alcohols (ESI Fig. S1-2†). The gas phase MS analysis clearly showed the formation of methane and butane from ethanol, respectively pentanol. Using deuterated ethanol with these hydride catalysts, we observed the formation of $\mathrm{CD}_{3} \mathrm{H}$ confirming the interaction of the hydride-site with the substrate. Moreover, we confirmed the molar mass of complex 3 via the LIFDI-MS technique (ESI Fig. S3†). Mechanistic investigations of decarbonylation reactions with ruthenium complexes were pioneered by Kubas and Caulton. ${ }^{25}$ Following these observations and other indications, ${ }^{28,29}$ Sabo-Etienne et al. reported the decarbonylation reaction of alcohol by a molecular dihydrogen ruthenium complex, whereby, similar to our system, the dihydrogen ligand is replaced by a CO ligand. ${ }^{22}$ Moreover, Foxman and Ozerov reported the CO functionalisation of a PNP type ruthenium pincer hydride complex obtained through decarbonylation of acetone. ${ }^{23}$ Based on previous reports by Milstein et al., we accordingly assume that a cis-[ $\left.\mathrm{RuH}_{2}(\mathrm{CO})(\mathrm{Me}-\mathrm{PNP})\right]$ complex is generated in the first step, which undergoes then, despite the high trans influence of the hydride ligands, a rapid cistrans isomerisation into the thermodynamically more stable and sterically more favourable trans isomer $3 .^{28,30-33}$ Furthermore, we observed no isomeric change in the ${ }^{1} \mathrm{H}-$ and ${ }^{31} \mathrm{P}\left\{{ }^{1} \mathrm{H}\right\}$ NMR after heating complex 3 at $80{ }^{\circ} \mathrm{C}$ for $10 \mathrm{~h}$. [ $\mathrm{RuH}_{2}(\mathrm{CO})-$ (Me-PNP)] 3 shows in the ${ }^{1} \mathrm{H}$-NMR spectrum at $300 \mathrm{MHz}$ a multiplet assigned to two hydrides at $-5.40 \mathrm{ppm}$. At higher frequencies of $600 \mathrm{MHz}$, the multiplet resolves into two clean triplet signals at $-5.43 \mathrm{ppm}\left({ }^{2} J_{\mathrm{HP}}=16.1 \mathrm{~Hz}\right)$ and $-5.54 \mathrm{ppm}$ $\left({ }^{2} J_{\mathrm{HP}}=19.3 \mathrm{~Hz}\right)$. Two signals for two hydride signals next to

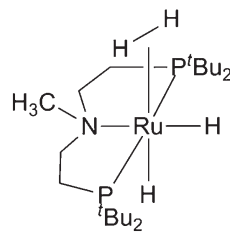

2

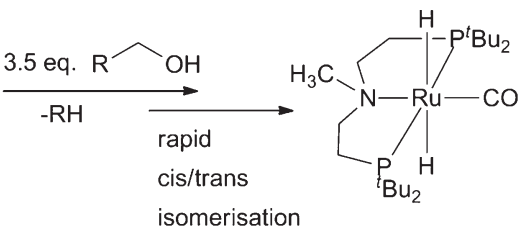

$\mathrm{R}=$ pentyl, methyl

3
Scheme 1 Decarbonylation of $\left[\mathrm{Ru}\left(\mathrm{H}_{2}\right) \mathrm{H}_{2}(\mathrm{Me}-\mathrm{PNP})\right] 2$ to $\left[\mathrm{RuH}_{2}(\mathrm{CO})(\mathrm{Me}-\right.$ $\mathrm{PNP})] 3$ via cis/trans isomerisation reaction. each other in the chemical shifts with a ${ }^{2} J_{\mathrm{HP}}$ coupling constant between 16 and $24 \mathrm{~Hz}$ is similar to other reported trans dihydride PNP pincer complexes with aliphatic backbones by Gusev and Schneider. ${ }^{34-37}$ In the ${ }^{13} \mathrm{C}-\mathrm{NMR}$ spectrum, the CO signal was found at $210.8 \mathrm{ppm}\left(\mathrm{t},{ }^{2} J_{\mathrm{CP}}=13.2 \mathrm{~Hz}\right)$, which was further confirmed by decarbonylation reactions of ${ }^{13} \mathrm{C}$ labeled ethanol (ESI, Fig. S16 $\dagger$ ). The $v \mathrm{CO}$ band was detected at $1871 \mathrm{~cm}^{-1}$ while the comparable ${ }^{13} \mathrm{CO}$ band was found with a $\Delta 43$ at $1828 \mathrm{~cm}^{-1}$. Vibration of the hydrides was found at $1642 \mathrm{~cm}^{-1}$ for complex 3 and $1640 \mathrm{~cm}^{-1}$ for the ${ }^{13} \mathrm{C}$ labeled complex (ESI, Fig. S10 $\dagger$ ). This is in agreement with the case of a typical trans dihydride arrangement. The CO stretching mode is located in the typical range with higher wave numbers followed by the $M-H$ vibrations as one single, sharp band at lower wave numbers. ${ }^{30,32,38}$ In contrast, for cis bonding modes of metal dihydrides, the hydride trans to a pincer backbone would have the highest wave number, followed then by the CO band and then with the lowest wave number the hydride trans to the carbonyl ligand. ${ }^{38}$

Comparing the decarbonylation reactivity of 2 , similar observations were made from the reaction of the analogue ruthenium complex $\left[\mathrm{Ru}\left(\mathrm{H}_{2}\right) \mathrm{H}(\mathrm{PNP})\right] \mathbf{5}$ whose synthesis was reported in earlier studies (Scheme 2). ${ }^{20,26}$ Decarbonylation reaction of ethanol by complex 5 gave the carbonyl complex $[\mathrm{RuH}(\mathrm{CO})(\mathrm{PNP})] 6$ in excellent yields. In the ${ }^{1} \mathrm{H}-\mathrm{NMR}$ spectrum, the hydride ligand gives a triplet signal in the upfield at $-20.87 \mathrm{ppm}\left({ }^{2} J_{\mathrm{HP}}=16.3 \mathrm{~Hz}\right)$, which indicates the configuration of the hydride ligand cis to the pincer ligand. ${ }^{34}$ Experiments with ${ }^{13} \mathrm{C}$ labeled ethanol resulted in a triplet signal at $208.8 \mathrm{ppm}\left({ }^{2} J_{\mathrm{CP}}=10.5 \mathrm{~Hz}\right)$ for the $\mathrm{CO}$ ligand in the ${ }^{13} \mathrm{C}_{\mathrm{APT}^{-}}$ NMR spectrum. IR signals were found at $1872 \mathrm{~cm}^{-1}$ for the non-labeled $\nu \mathrm{CO}$ vibration along with a weaker $\nu \mathrm{Ru}-\mathrm{H}$ band at $2052 \mathrm{~cm}^{-1}$ which are characteristic of pincer based carbonyl monohydride compounds. ${ }^{30}$ For the ${ }^{13} \mathrm{C}$ labeled complex, the ${ }^{13} \mathrm{CO}$ band was detected at $1830 \mathrm{~cm}^{-1}$ and with a $\nu \mathrm{Ru}-\mathrm{H}$ vibration around $2062 \mathrm{~cm}^{-1}$ (Fig. S13†). Pressurising complex 6 with 1.5 bar $\mathrm{H}_{2}$ gas showed around 79\% conversion of 6 into trans dihydride 7, which exhibits, similar to complex 3, two triplet signals at $-5.86 \mathrm{ppm}\left({ }^{2} J_{\mathrm{HP}}=18.2 \mathrm{~Hz}\right)$ and $-6.13 \mathrm{ppm}$

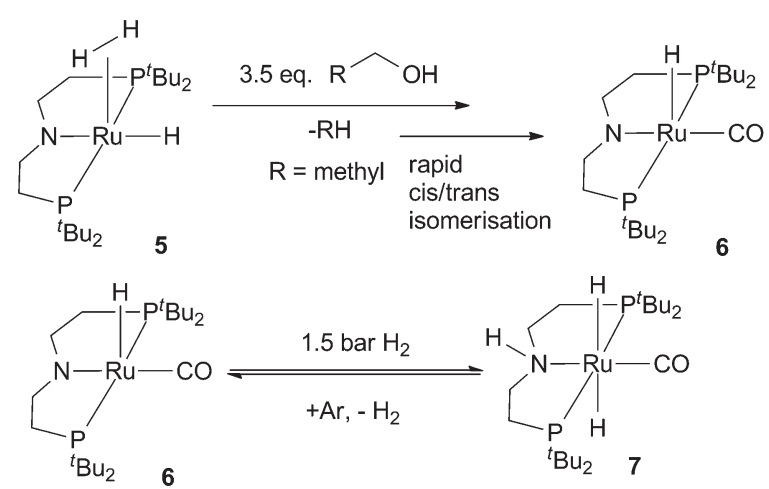

Scheme 2 Decarbonylation of $\left[\mathrm{Ru}\left(\mathrm{H}_{2}\right) \mathrm{H}(\mathrm{PNP})\right] 5$ to $[\mathrm{RuH}(\mathrm{CO})(\mathrm{PNP})] 6$ via cis/trans isomerisation and the hydrogenation of 6 to $\left[\mathrm{RuH}_{2}(\mathrm{CO})\right.$ (HPNP)] 7. 
$\left({ }^{2} J_{\mathrm{HP}}=17.4 \mathrm{~Hz}\right)$. Isolation of complex 7 was not possible due to the rapid degeneration into 6 .

\section{Catalytic cycle and the isolation of intermediates $4 a$ and $b$}

Similar to the system reported by Milstein et al., we assume that complex 3 dehydrogenates the alcohol into an aldehyde intermediate complex. It is also possible that the aldehyde converts independently with water into an aldehyde hydrate intermediate. However, due to the rapid equilibrium between the aldehyde and the aldehyde hydrate intermediate, ${ }^{11}$ it seems more plausible that the reaction with water under basic conditions generates an aldehyde hydrate, stabilised as a geminial diolate complex, which can be dehydrogenated into the carboxylate complex $4 \mathbf{a}$ (Fig. 3). ${ }^{11}$ From there on, the carboxylate is salted out by sodium cations. In the presence of water, no formation of esters was observed since only unreacted alcohol residues were found in the reaction mixture after the appropriate reaction time. This observation confirms yet again that water suppresses the formation of ester. ${ }^{11}$ Compared to previous studies $^{11}$ it is unclear whether the mechanism involves a metal-ligand cooperativity during the catalytic reaction. We achieved the conversion of alcohols to carboxylic acids using catalysts 2 and $\mathbf{3}$ bearing a "non-cooperative" Me-PNP-ligand. The experimental data show that a basic position as a proton acceptor/donor is not crucial for this reaction as no H/D exchange has been observed in the ligand backbone. The lack of H/D exchange in the ligand backbone lets us tentatively exclude cooperative effects of the ligand. It is likely that the acceptorless dehydrogenation and oxygen-transfer from water solely take place at the ruthenium core.

The attempt to isolate the complex intermediate species after the reaction time led to the isolation of $\mathbf{4 a}$ which was extracted with toluene. Separate attempts led also to the isolation of $4 \mathbf{a}$ either by refluxing complex 2 in hexyl alcohol and water or by the reaction of $\mathbf{3}$ with hexanoic acid (Fig. 3). For the latter one, $\mathbf{4 a}$ was obtained in very good yields within minutes under hydrogen evolution. The analogue, complex $\mathbf{4} \mathbf{b}$, was obtained by adding acetic acid to complex 3 (Fig. 3).

Both complexes almost do not differ in their chemical shifts in the ${ }^{31} \mathrm{P}\left\{{ }^{1} \mathrm{H}\right\}$ NMR showing singlets around $81.4 \mathrm{ppm}$ (complex 4a) and 81.3 (complex 4b), while exhibiting triplet

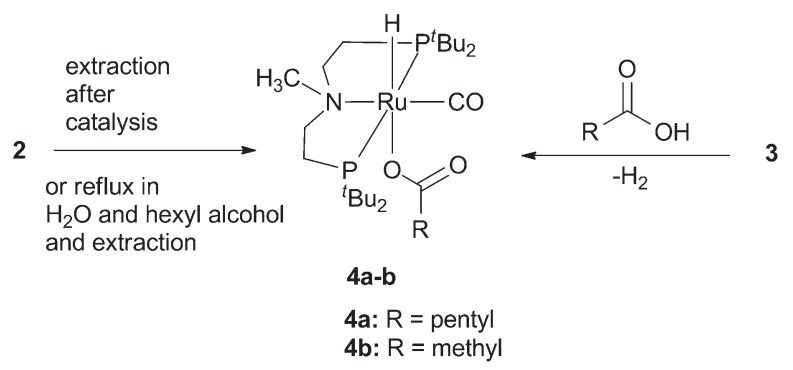

Fig. 3 Isolation of complexes $4 a$ and $4 \mathrm{~b}$. Complex $4 a$ was obtained by extraction with toluene after the catalytic reaction with 2 or by refluxing 2 with hexyl alcohol in water. Adding acetic or hexanoic acid to complex 3 led directly to $4 a$ and $4 b$.

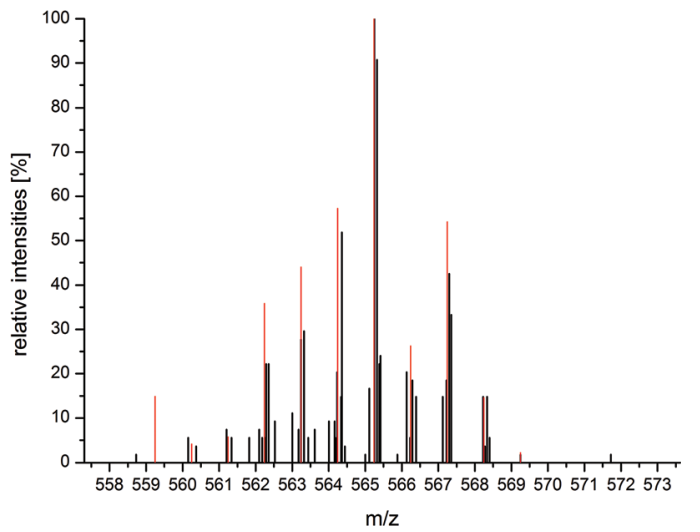

Fig. 4 LIFDI-MS/MS analysis of $\left[\mathrm{RuH}(\mathrm{CO})\left(\mathrm{OOCCH}_{3}\right)(\mathrm{Me}-\mathrm{PNP})\right] 565$ 4b in toluene. Isotope pattern area 558-570 (black) in comparison with the simulated isotope pattern of $\left[\mathrm{RuH}(\mathrm{CO})\left(\mathrm{OOCCH}_{3}\right)(\mathrm{Me}-\mathrm{PNP})\right] 565$ (red).

signals in the upfield at $-17.08 \mathrm{ppm}\left({ }^{2} J_{\mathrm{PH}}=20.7 \mathrm{~Hz}\right.$, complex 4a) and at $-17.49 \mathrm{ppm}\left({ }^{2} J_{\mathrm{PH}}=20.4 \mathrm{~Hz}\right.$, complex 4b). IR spectra show the $\nu \mathrm{CO}$ for both complexes at $1908 \mathrm{~cm}^{-1}$, while exhibiting the $\nu \mathrm{C}=\mathrm{O}$ band at $1593 \mathrm{~cm}^{-1}$ (ESI, Fig. S11-12 $\dagger$ ). LIFDI-MS/MS analysis of complex 4a showed only a fragmentation with the mass value of $506 \mathrm{~m} / \mathrm{z}$, which can be explained by the loss of the hexanoate under MS conditions, showing only the carbonyl monohydride species (for more details see ESI, Fig. S5-6†). This observation is in full agreement with our recent experiments applying LIFDI-MS analysis to ruthenium pincer hydride complexes. ${ }^{20}$ During a soft ionisation process, a mixture of similar fragmentations can be detected with this kind of compound class, which can be explained by the loss of the hydride ligands $(-\Delta 1-2 \mathrm{~m} / \mathrm{z})$ causing a shift towards lower mass values. ${ }^{20}$ In contrast to $\mathbf{4 a}$, LIFDI-MS/MS analysis of $\mathbf{4 b}$ revealed the molar mass of $565 \mathrm{~m} / z$, which is in good agreement with the simulated isotope pattern (in red) illustrated in Fig. 4. Compared to the simulated isotope pattern of [ $\mathrm{RuH}(\mathrm{CO})-$ $\left.\left(\mathrm{OOCCH}_{3}\right)(\mathrm{Me}-\mathrm{PNP})\right] 565 \mathrm{~m} / \mathrm{z}$ in red, the LIFDI-MS/MS pattern is slightly shifted towards lower mass value, which can be explained by the detection of a fragmentation of the subspecies $\left[\mathrm{Ru}(\mathrm{CO})\left(\mathrm{OOCCH}_{3}\right)(\mathrm{Me}-\mathrm{PNP})\right] 564$ which is generated during the ionisation process.

A single crystal structure of $\mathbf{4 b}$ was obtained from crystals grown as a red prism in a mixture of benzene and heptane at room temperature (Fig. 5, selected bond distances and angles are given in Table 2). The structure shows a distorted octahedral coordination of the ruthenium core, where both locations of the $\mathrm{P}$-atoms of the $\mathrm{P}-\mathrm{Ru}-\mathrm{P}$ axis are twisted out-ofplane with a P1-Ru-P2 angle of 157.24․ The same applies for the trans-arrangement of the hydride and the carboxylate with an angle of $169.20^{\circ}$ (H1-Ru-O2). The X-ray pattern allowed the localisation of the hydride $\mathrm{H} 1$ giving a $\mathrm{Ru}-\mathrm{H}$ distance of 1.57(4) A. Furthermore, the trans arrangement of the CO ligand to the PNP-ligand is confirmed, which was discussed earlier in this work. The $\mathrm{N}-\mathrm{Ru}-\mathrm{CO}$ angle is closer to $180^{\circ}$ $\left(176.16^{\circ}\right)$; consequently the $\mathrm{H} 1-\mathrm{Ru}-\mathrm{CO}$ angle is near orthogonal $\left(92.20^{\circ}\right)$. 


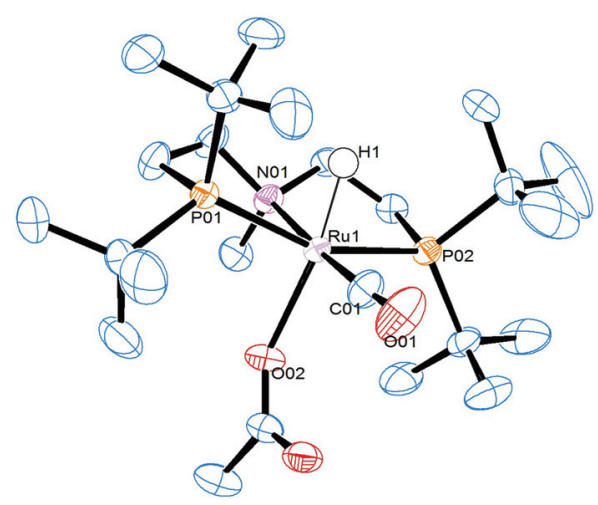

Fig. 5 ORTEP diagram of the single crystal structure of complex $4 \mathrm{~b}$. Ellipsoids are illustrated at $50 \%$ probability. All hydrogen atoms are not depicted here except for $\mathrm{H} 1$ for clarity.

Table 2 Selected bond distances ${ }^{a}$ and angles ${ }^{b}$ of complex $4 b$

\begin{tabular}{lllr}
\hline Ru1-P1 & $2.34(9)$ & P1-Ru1-P2 & 157.24 \\
Ru1-P2 & $2.34(6)$ & N01-Ru1-C01 & 176.16 \\
Ru1-C01 & $1.82(0)$ & H1-Ru1-O02 & 169.30 \\
Ru1-O02 & $2.21(9)$ & H1-Ru1-C01 & 92.20 \\
Ru1-H1 & $1.57(4)$ & & \\
Ru1-N01 & $2.24(7)$ & &
\end{tabular}

${ }^{a}$ Distances are given in $\AA .{ }^{b}$ Angles are reported in degrees.

\section{Conclusions}

In summary, we presented an approach for catalytic dehydrogenation of primary alcohols in water yielding carboxylic acid salts using ruthenium hydride complexes. Moreover, we confirmed that complexes $\mathbf{2}$ and $\mathbf{5}$ convert in situ into carbonyl trans dihydride complexes 3 and 6 by decarbonylation reaction of alcohols. Complex intermediate $\mathbf{4 a}$, which was isolated after the catalysis as well as synthesised in different ways, is believed to be one of the complex species taking part in the catalytic cycle.

\section{Experimental section}

Reactions were generally performed under an argon atmosphere using Schlenk techniques, flame-dried glassware and a Labmaster 200 glove-box from MBraun. High-pressure hydrogen reactions were performed in a Büchi Tinyclave $(50 \mathrm{~mL})$ glass autoclave. All solvents and reagents were purchased from Acros, Merck, Sigma-Aldrich, Fluka, or Strem or were acquired from the institute stock. Commercial anhydrous solvents and argon as-packed reagents were used as received and stored in the glove-box under argon. Non-anhydrous solvents were dried and distilled (under vacuum or argon) prior to use, applying standard procedures. +

\$For the Experimental section, limited spectral and crystallographic data, see ESI.

\section{Analytical methods}

${ }^{1} \mathrm{H}-,{ }^{13} \mathrm{C}-,{ }^{31} \mathrm{P}-\mathrm{NMR}$ spectra were recorded at $300 \mathrm{MHz}\left({ }^{1} \mathrm{H}\right)$, $75 \mathrm{MHz}\left({ }^{13} \mathrm{C}\right)$ and $121 \mathrm{MHz}\left({ }^{31} \mathrm{P}\right)$ on a Bruker Avance II 300 and on a Bruker Avance II+ 600 spectrometer at $600 \mathrm{MHz}\left({ }^{1} \mathrm{H}\right)$, $150 \mathrm{MHz}\left({ }^{13} \mathrm{C}\right)$ and $242 \mathrm{MHz}\left({ }^{31} \mathrm{P}\right)$ using deuterated benzene and toluene at room temperature. ${ }^{1} \mathrm{H}$ shifts were reported in ppm $\left(\delta_{\mathrm{H}}\right)$ downfield from TMS and were determined by reference to the residual solvent peaks $\left(\mathrm{C}_{6} \mathrm{D}_{6}: 7.16 \mathrm{ppm}, \mathrm{C}_{7} \mathrm{D}_{8}\right.$ : 7.09 ppm.). Chemical shifts were reported as singlet (s), doublet $(\mathrm{d})$, triplet $(\mathrm{t})$, quartet $(\mathrm{q})$ and multiplet $(\mathrm{m})$. Coupling constants $J$ were reported in $\mathrm{Hz}$. For hydrogenation experiments, Young-Teflon capped NMR tubes from Wilmad were used. Infrared spectra (IR) were measured at room temperature with a Bruker Alpha spectrometer equipped with a DiamondATR IR unit. Data are reported as follows: absorption $\tilde{\nu}\left[\mathrm{cm}^{-1}\right]$, weak (w), medium (m), strong (s). Mass-spectrometric investigations of the gas composition in the gas phase were conducted with a HPR-20 gas analysis system by Hiden Analytical and were directly connected to the reaction setup under an argon atmosphere. The HPR-20 QIC (Hiden Analytical) has a MS detection limit $<0.09 \mathrm{ppm}$ as xenon in air is detectable. Note that the MS has sensitivity down to partial pressures of $10^{-10}$ torr (note: the spectrometer specific unit is torr not $\mathrm{MPa})$.

\section{General catalytic procedure}

For the standard catalytic procedure, $0.05 \mathrm{mmol}$ of complex 2 or complex 3 were added to $5.5 \mathrm{mmol} \mathrm{NaOH}$ and $5 \mathrm{mmol}$ of alcohol. After the addition of $2 \mathrm{~mL}$ degassed water, the content was refluxed at $120{ }^{\circ} \mathrm{C}$ for $20 \mathrm{~h}$ under constant argon flow in an open system. After the reaction time, the aqueous phase was extracted with diethyl ether to extract the catalyst and alcohol residues. The aqueous layer was then acidified with $20 \%$ aq. $\mathrm{HCl}$ and treated five times with $20 \mathrm{~mL}$ ethyl acetate. After the organic layers were combined and dried for $1 \mathrm{~h}$ over $\mathrm{MgSO}_{4}$, the solution was filtered and the solvent was removed under reduced pressure to obtain the isolated carboxylic acid. Yields are given in Table 1.

\section{Synthesis of $\left[\mathrm{RuH}_{2}(\mathrm{CO})(\mathrm{Me}-\mathrm{PNP})\right] 3$}

In an argon flushed Büchi glass autoclave $100 \mathrm{mg}$ $(0.198 \mathrm{mmol})$ of $\left[\mathrm{Ru}\left(\mathrm{H}_{2}\right) \mathrm{H}_{2}(\mathrm{Me}-\mathrm{PNP})\right] 2$ were dissolved in $6 \mathrm{~mL}$ toluene. The synthesis of complex 2 is described in our previous report. ${ }^{20}$ After the addition of 3.5 eq. (0.693 mmol) of a primary alcohol (e.g. ethyl, pentyl, hexyl alcohol), the content was heated at $80{ }^{\circ} \mathrm{C}$ for $48 \mathrm{~h}$. After the appropriate time, the solvent was removed in vacuo and the residue was washed twice with pentane. The grey powder was stored at $-34{ }^{\circ} \mathrm{C}$. Yield: $80 \%$.

LIFDI-MS (argon collided): $m / z 511.3$ (2), 510.3 (19), 509.3 (55), 508.3 (33), 507.3 (100), 506.3 (73), 505.3 (74), 504.3 (65), 503.3 (30), 502.3 (17), 501.3 (22).

${ }^{1} \mathrm{H}-\mathrm{NMR}:\left(600 \mathrm{MHz}\right.$, benzene-d $\left.\mathrm{d}_{6}\right): \delta_{\mathrm{H}}[\mathrm{ppm}]=2.32(\mathrm{~m}, 2 \mathrm{H}$, $\left.\mathrm{CH}_{2}\right), 2.11\left(\mathrm{~s}, 3 \mathrm{H}, \mathrm{NCH}_{3}\right), 1.93\left(\mathrm{~m}, 2 \mathrm{H}, \mathrm{NCH}_{2}\right), 1.61(\mathrm{~m}, 2 \mathrm{H}$, $\mathrm{PCH}_{2}$ ), 1.55-1.52 (m, 2H, overlapped, $\mathrm{PCH}_{2}$ ), 1.50 (dt, $36 \mathrm{H}$, 
$\left.{ }^{3} J_{\mathrm{PH}}=6.7 \mathrm{~Hz}, \mathrm{PC}\left(\mathrm{CH}_{3}\right)_{3}\right),-5.43\left(\mathrm{t}, 1 \mathrm{H},{ }^{2} J_{\mathrm{PH}}=16.1 \mathrm{~Hz}, \mathrm{Ru}-\mathrm{H}\right)$, $-5.54\left(\mathrm{t}, 1 \mathrm{H},{ }^{2} J_{\mathrm{PH}}=19.4 \mathrm{~Hz}, \mathrm{Ru}-\mathrm{H}\right)$.

${ }^{13} \mathrm{C}_{\mathrm{APT}}$-NMR: (75 MHz, benzene- $\mathrm{d}_{6}$ ): $\delta_{\mathrm{C}}[\mathrm{ppm}]=210.8 \mathrm{ppm}$ ( $\mathrm{t},{ }^{2} J_{\mathrm{CP}}=13.2 \mathrm{~Hz}, \mathrm{CO}$, data extracted from ${ }^{13} \mathrm{CO}$ labeled probe), $65.8\left(\mathrm{t},{ }^{2} J_{\mathrm{CP}}=5.1 \mathrm{~Hz}, \mathrm{NCH}_{2}\right), 52.9\left(\mathrm{NCH}_{3}\right), 36.4\left(\mathrm{t},{ }^{1} J_{\mathrm{CP}}=8.9 \mathrm{~Hz}\right.$, $\left.\mathrm{P}\left(C\left(\mathrm{CH}_{3}\right)_{3}\right)\right), 33.9\left(\mathrm{t},{ }^{1} J_{\mathrm{CP}}=7.4 \mathrm{~Hz}, \mathrm{P}\left(C\left(\mathrm{CH}_{3}\right)_{3}\right)\right), 30.3\left(\mathrm{t},{ }^{2} J_{\mathrm{CP}}=\right.$ $3.3 \mathrm{~Hz}, \mathrm{P}\left(\mathrm{C}\left(\mathrm{CH}_{3}\right)_{3}\right), 30.1\left(\mathrm{t},{ }^{2} \mathrm{~J}_{\mathrm{CP}}=2.9 \mathrm{~Hz}, \mathrm{P}\left(\mathrm{C}\left(\mathrm{CH}_{3}\right)_{3}\right)\right), 24.4(\mathrm{t}$, $\left.{ }^{1} J_{\mathrm{CP}}=5.3 \mathrm{~Hz}, \mathrm{PCH}_{2}\right)$.

${ }^{31} \mathrm{P}\left\{{ }^{1} \mathrm{H}\right\}-N M R:\left(121 \mathrm{MHz}\right.$, benzene-d $\left.\mathrm{d}_{6}\right): \delta_{\mathrm{P}}[\mathrm{ppm}]=106.3(\mathrm{~s})$.

IR: $\tilde{\nu}\left[\mathrm{cm}^{-1}\right]=2950-2864(\mathrm{~m}), 1871(\mathrm{~s}), 1640(\mathrm{~s}), 1474(\mathrm{~m})$, $1458(\mathrm{~m}), 1416(\mathrm{w}), 1383(\mathrm{~m}), 1381$ (m), $1351(\mathrm{~m}), 1310(\mathrm{w})$, 1208 (w), 1171 (m), 1049 (w), 1025 (m), $930(\mathrm{w}), 915$ (w), 881 (m), 801 (m), $739(\mathrm{~m}), 679(\mathrm{~m}), 644(\mathrm{w}), 613(\mathrm{~m}), 566(\mathrm{~m}), 529$ (w), $508(\mathrm{w}), 478(\mathrm{~m}), 432(\mathrm{~m})$.

\section{Isolation of $[\mathrm{RuH}(\mathrm{CO})($ hexanolate $)(\mathrm{Me}-\mathrm{PNP})] \mathrm{4a}$}

In an argon flushed Schlenk flask equipped with a bubbler, $50 \mathrm{mg}(0.1 \mathrm{mmol})$ of $\left[\mathrm{RuH}_{2}(\mathrm{CO})(\mathrm{Me}-\mathrm{PNP})\right] 3$ were dissolved in $5 \mathrm{~mL}$ toluene. After the addition of $1.5 \mathrm{eq}$. (0.15 mmol) hexanoic acid, the content was stirred for 30 min under a constant stream of argon. The solvent was removed in vacuo and the product was washed twice with pentane. The grey powder, yielding $85 \%$, was stored at $-34{ }^{\circ} \mathrm{C}$.

LIFDI-MS/MS (fragment 506): $m / z 509.3$ (13.1), 508.3 (33.3), 507.3 (16.7), 507.2 (9.5), 506.3 (100), 505.3 (97.6), 504.3 (47.6), 503.3 (16.7), 502.2 (16.7), 501.1 (4.8), 500.2 (9.5).

${ }^{1} \mathrm{H}-\mathrm{NMR}:\left(600 \mathrm{MHz}\right.$, benzene- $\left.\mathrm{d}_{6}\right): \delta_{\mathrm{H}}[\mathrm{ppm}]=2.51(\mathrm{t}, 2 \mathrm{H}$, $\left.{ }^{2} J_{\mathrm{CH}}=7.6 \mathrm{~Hz}, \mathrm{OOCCH}_{2}\left(\mathrm{CH}_{2}\right)_{3} \mathrm{CH}_{3}\right), 2.17\left(\mathrm{~s}, 3 \mathrm{H}, \mathrm{NCH}_{3}\right), 2.14$ $\left(\mathrm{m}, 4 \mathrm{H}, \quad \mathrm{NCH}_{2}\right), 1.70\left(\mathrm{~m}, 2 \mathrm{H}, \mathrm{OOCCH}_{2} \mathrm{CH}_{2}\left(\mathrm{CH}_{2}\right)_{2} \mathrm{CH}_{3}\right)$, 1.55-1.51 (m, 8H, overlapped, $4 \mathrm{H} \mathrm{PCH}_{2}$ and $4 \mathrm{H}$ OOC $\left.\left(\mathrm{CH}_{2}\right)_{2}\left(\mathrm{CH}_{2}\right)_{2} \mathrm{CH}_{3}\right), 1.38\left(\mathrm{t}, 18 \mathrm{H},{ }^{3} J_{\mathrm{PH}}=6.5 \mathrm{~Hz}, \mathrm{P}\left(\mathrm{C}\left(\mathrm{CH}_{3}\right)_{3}\right), 1.23\right.$ $\left(\mathrm{t}, 18 \mathrm{H},{ }^{3} J_{\mathrm{PH}}=6.1 \mathrm{~Hz}, \mathrm{P}\left(\mathrm{C}\left(\mathrm{CH}_{3}\right)_{3}\right), 0.99\left(\mathrm{t}, 3 \mathrm{H},{ }^{2} J_{\mathrm{CH}}=7.3 \mathrm{~Hz}\right.\right.$, $\left.\operatorname{OOC}\left(\mathrm{CH}_{2}\right)_{4} \mathrm{CH}_{3}\right),-17.08\left(\mathrm{t}, 1 \mathrm{H},{ }^{2} \mathrm{~J}_{\mathrm{PH}}=20.7 \mathrm{~Hz}, \mathrm{Ru}-\mathrm{H}\right)$.

${ }^{13} \mathrm{C}_{\text {DeptQ }}$-NMR: $\left(150 \mathrm{MHz}\right.$, benzene- $\left.\mathrm{d}_{6}\right): \delta_{\mathrm{C}}[\mathrm{ppm}]=$ 208.5 ppm (s, CO), 175.8 (s, $\left.\mathrm{CH}_{3} \mathrm{COO}\right), 65.8$ (s, $\mathrm{NCH}_{2}$ ), 45.6 (s, $\left.\mathrm{NCH}_{3}\right), 40.8\left(\mathrm{~s}, \mathrm{OOCCH}_{2}\left(\mathrm{CH}_{2}\right)_{3} \mathrm{CH}_{3}\right), 37.5\left(\mathrm{t},{ }^{1} J_{\mathrm{PC}}=5.1 \mathrm{~Hz}\right.$, $\left.\mathrm{P}\left(C\left(\mathrm{CH}_{3}\right)_{3}\right)\right), 36.8\left(\mathrm{t},{ }^{1} J_{\mathrm{PC}}=10.3 \mathrm{~Hz}, \mathrm{P}\left(C\left(\mathrm{CH}_{3}\right)_{3}\right)\right), 33.0(\mathrm{~s}$, $\left.\mathrm{OOCCH}_{2} \mathrm{CH}_{2}\left(\mathrm{CH}_{2}\right)_{2} \mathrm{CH}_{3}\right), \quad 30.6$ (s, $\mathrm{P}\left(\mathrm{C}\left(\mathrm{CH}_{3}\right)_{3}\right), \quad 30.5$ (s, $\left.\mathrm{P}\left(\mathrm{C}\left(\mathrm{CH}_{3}\right)_{3}\right)\right), 27.2\left(\mathrm{~s}, \mathrm{OOC}\left(\mathrm{CH}_{2}\right)_{2} \mathrm{CH}_{2} \mathrm{CH}_{2} \mathrm{CH}_{3}\right), 23.7$ (s, OOC$\left.\left(\mathrm{CH}_{2}\right)_{3} \mathrm{CH}_{2} \mathrm{CH}_{3}\right), 23.4\left(\mathrm{~s}, \mathrm{PCH}_{2}\right), 14.2\left(\mathrm{~s}, \mathrm{OOC}\left(\mathrm{CH}_{2}\right)_{4} \mathrm{CH}_{3}\right)$.

${ }^{31} \mathrm{P}\left\{{ }^{1} \mathrm{H}\right\}-\mathrm{NMR}:\left(121 \mathrm{MHz}\right.$, benzene- $\left.{ }_{6}\right): \delta_{\mathrm{P}}[\mathrm{ppm}]=81.4(\mathrm{~s})$.

IR: $\tilde{\nu}\left[\mathrm{cm}^{-1}\right]=2959-2868(\mathrm{~m}), 2126-2075(\mathrm{w}), 1908(\mathrm{~s})$, 1595 (s), 1466 (m), 1429 (w), 1389 (m), 1369 (m), 1354 (m), $1175(\mathrm{~m}), 1043(\mathrm{~m}), 1024(\mathrm{~m}), 958(\mathrm{w}), 933(\mathrm{w}), 907(\mathrm{w})$, $879(\mathrm{~m}), 828(\mathrm{w}), 807(\mathrm{~m}), 736(\mathrm{~m}), 680(\mathrm{~m}), 643(\mathrm{~m}), 609(\mathrm{~m})$, $570(\mathrm{~m}), 546(\mathrm{~m}), 531(\mathrm{~m})$.

\section{Isolation of $\left[\mathrm{RuH}(\mathrm{CO})\left(\mathrm{OOCCH}_{3}\right)(\mathrm{Me}-\mathrm{PNP})\right] 4 \mathrm{~b}$}

In an argon flushed Schlenk flask equipped with a bubbler, $30 \mathrm{mg}(0.06 \mathrm{mmol})$ of $\left[\mathrm{RuH}_{2}(\mathrm{CO})(\mathrm{Me}-\mathrm{PNP})\right] 3$ were dissolved in $5 \mathrm{~mL}$ toluene. After the addition of $1.5 \mathrm{eq}$. (0.09 mmol) acetic acid, the content was stirred for $30 \mathrm{~min}$ under a constant stream of argon. The solvent was removed in vacuo and the product was washed twice with pentane. The grey powder, yielding $81 \%$, was stored at $-34{ }^{\circ} \mathrm{C}$.
LIFDI-MS/MS: $m / z 569.2$ (1.9), 568.2 (14.8), 567.3 (42.6), 566.3 (18.5), 565.3 (100), 564.4 (51.9), 563.2 (27.8), 561.2 (7.4), 560.2 (5.6).

${ }^{1} \mathrm{H}-\mathrm{NMR}:\left(600 \mathrm{MHz}\right.$, benzene- $\left.\mathrm{d}_{6}\right): \delta_{\mathrm{H}}[\mathrm{ppm}]=2.22(\mathrm{~s}, 3 \mathrm{H}$, $\left.\mathrm{OOCCH}_{3}\right), 2.13\left(\mathrm{~m}, 4 \mathrm{H}, \mathrm{NCH}_{2}\right), 2.09\left(\mathrm{~s}, 3 \mathrm{H}, \mathrm{NCH}_{3}\right), 1.63(\mathrm{~m}, 2 \mathrm{H}$ $\left.\mathrm{PCH}_{2}\right), 1.49\left(\mathrm{~m}, 2 \mathrm{H}, \mathrm{PCH}_{2}\right), 1.31\left(\mathrm{t}, 18 \mathrm{H},{ }^{3} J_{\mathrm{PH}}=6.4 \mathrm{~Hz}\right.$, $\mathrm{P}\left(\mathrm{C}\left(\mathrm{CH}_{3}\right)_{3}\right), 1.18\left(\mathrm{t}, 18 \mathrm{H},{ }^{3} J_{\mathrm{PH}}=6.2 \mathrm{~Hz}, \mathrm{P}\left(\mathrm{C}\left(\mathrm{CH}_{3}\right)_{3}\right),-17.49(\mathrm{t}\right.$, $\left.1 \mathrm{H},{ }^{2} J_{\mathrm{PH}}=20.4 \mathrm{~Hz}, \mathrm{Ru}-\mathrm{H}\right)$.

${ }^{13} \mathrm{C}_{\text {DeptQ }}$-NMR: $\left(150 \mathrm{MHz}\right.$, benzene-d $\left.\mathrm{d}_{6}\right): \delta_{\mathrm{C}}[\mathrm{ppm}]=$ $208.8 \mathrm{ppm}(\mathrm{s}, \mathrm{CO}), 175.4$ (s, $\left.\mathrm{CH}_{3} \mathrm{COO}\right), 65.7$ (s, $\left.\mathrm{NCH}_{2}\right), 45.2$ (s, $\left.\mathrm{NCH}_{3}\right), 37.2\left(\mathrm{t},{ }^{1} J_{\mathrm{CP}}=5.3 \mathrm{~Hz}, \mathrm{P}\left(C\left(\mathrm{CH}_{3}\right)_{3}\right)\right), 36.7\left(\mathrm{t},{ }^{1} J_{\mathrm{CP}}=\right.$ $\left.10.2 \mathrm{~Hz}, \mathrm{P}\left(\mathrm{C}\left(\mathrm{CH}_{3}\right)_{3}\right)\right), 30.5\left(\mathrm{~s}, \mathrm{P}\left(\mathrm{C}\left(\mathrm{CH}_{3}\right)_{3}\right), 30.2\left(\mathrm{~s}, \mathrm{P}\left(\mathrm{C}\left(\mathrm{CH}_{3}\right)_{3}\right)\right)\right.$, 23.6 (s, $\mathrm{PCH}_{2}$ ).

${ }^{31} \mathrm{P}\left\{{ }^{1} \mathrm{H}\right\}-\mathrm{NMR}:\left(242 \mathrm{MHz}\right.$, benzene-d $\left.\mathrm{d}_{6}\right): \delta_{\mathrm{P}}[\mathrm{ppm}]=81.3(\mathrm{~s})$.

IR: $\tilde{\nu}\left[\mathrm{cm}^{-1}\right]=2956-2859(\mathrm{~m}), 2145-2059(\mathrm{w}), 1906(\mathrm{~s})$, 1593 (s), 1464 (m), 1389 (m), 1368 (m), 1354 (m), 1259 (s), 1175 (m), 1087 (s), 1021 (s), 934 (w), 907 (w), 878 (m), 800 (s), $735(\mathrm{~m}), 680(\mathrm{~m}), 609(\mathrm{~m}), 569(\mathrm{~m}), 546(\mathrm{w}), 529(\mathrm{w}), 478(\mathrm{~m})$.

\section{Synthesis of $[\operatorname{RuH}(\mathrm{CO})(\mathrm{PNP})] 6$}

In an argon flushed Büchi glass autoclave $100 \mathrm{mg}$ $(0.215 \mathrm{mmol})$ of $\left[\mathrm{Ru}\left(\mathrm{H}_{2}\right) \mathrm{H}(\mathrm{PNP})\right] 5$ were dissolved in $6 \mathrm{~mL}$ toluene. The synthesis of complex 5 is described in our previous report. ${ }^{20}$ After the addition of 3.5 eq. $(0.753 \mathrm{mmol})$ of a primary alcohol (e.g. ethyl, pentyl, hexyl alcohol), the content was heated at $80^{\circ} \mathrm{C}$ for $48 \mathrm{~h}$. After the appropriate time, the solvent was removed in vacuo and the residue was washed twice with pentane. The orange powder was stored at $-34^{\circ} \mathrm{C}$. Yield: $90 \%$.

LIFDI-MS/MS: $m / z 495.1$ (1.0), 494.3 (15.9), 493.3 (46.1), 492.3 (14.6), 491.3 (100), 490.2 (34.7), 489.2 (39.6), 488.3 (28.9), 487.3 (4.6), 486.2 (2.4), 485.3 (15.5).

${ }^{1} \mathrm{H}-\mathrm{NMR}:\left(300 \mathrm{MHz}\right.$, benzene- $\left.\mathrm{d}_{6}\right): \delta_{\mathrm{H}}[\mathrm{ppm}]=3.49(\mathrm{~m}, 2 \mathrm{H}$, $\mathrm{CH}_{2}$ ), $3.14\left(\mathrm{~m}, 2 \mathrm{H}, \mathrm{CH}_{2}\right), 1.88\left(\mathrm{~m}, 4 \mathrm{H}, \mathrm{PCH}_{2}\right), 1.26$ (dt, 36H, $\left.{ }^{2} J_{\mathrm{PH}}=14.3 \mathrm{~Hz}, \mathrm{PC}\left(\mathrm{CH}_{3}\right)_{3}\right),-20.87\left(\mathrm{t}, 1 \mathrm{H},{ }^{2} J_{\mathrm{PH}}=16.3 \mathrm{~Hz}, \mathrm{Ru}-\mathrm{H}\right)$.

${ }^{13} \mathrm{C}_{\mathrm{APT}}$-NMR: (75 MHz, benzene- $\mathrm{d}_{6}$ ): $\delta_{\mathrm{C}}[\mathrm{ppm}]=208.8 \mathrm{ppm}$ $\left(\mathrm{t}, \mathrm{CO},{ }^{2} J_{\mathrm{CP}}=10.5 \mathrm{~Hz}\right.$, data extracted from ${ }^{13} \mathrm{CO}$ labeled probe in toluene- $\left.\mathrm{d}_{8}\right), 63.5\left(\mathrm{t},{ }^{2} J_{\mathrm{CP}}=7.1 \mathrm{~Hz}, \mathrm{NCH}_{2}\right), 35.4\left(\mathrm{t},{ }^{1} J_{\mathrm{CP}}=\right.$ $\left.7.7 \mathrm{~Hz}, \mathrm{P}\left(C\left(\mathrm{CH}_{3}\right)_{3}\right)\right), 33.9\left(\mathrm{t},{ }^{1} J_{\mathrm{CP}}=7.4 \mathrm{~Hz}, \mathrm{P}\left(C\left(\mathrm{CH}_{3}\right)_{3}\right)\right), 29.7$ (t, ${ }^{2} J_{\mathrm{CP}}=3.0 \mathrm{~Hz}, \mathrm{P}\left(\mathrm{C}\left(\mathrm{CH}_{3}\right)_{3}\right), 28.5\left(\mathrm{t},{ }^{2} J_{\mathrm{CP}}=3.2 \mathrm{~Hz}, \mathrm{P}\left(\mathrm{C}\left(\mathrm{CH}_{3}\right)_{3}\right)\right)$, $26.0\left(\mathrm{t},{ }^{1} J_{\mathrm{CP}}=6.9 \mathrm{~Hz}, \mathrm{PCH}_{2}\right)$.

${ }^{31} \mathrm{P}\left\{{ }^{1} \mathrm{H}\right\}-N M R:\left(121 \mathrm{MHz}\right.$, benzene- $\left.\mathrm{d}_{6}\right): \delta_{\mathrm{P}}[\mathrm{ppm}]=110.1(\mathrm{~s})$.

IR: $\tilde{\nu}\left[\mathrm{cm}^{-1}\right]=2943-2800(\mathrm{~m}), 2706(\mathrm{w}), 2628(\mathrm{w}), 2068-2048$ (m), 1869 (s), 1469 (m), 1454 (m), 1385 (m), 1358 (m), 1318 (w), $1262(\mathrm{~m}), 1206$ (m), 1178 (m), 1157 (w), 1106 (w), 1063 (m), $1017(\mathrm{~m}), 967(\mathrm{~m}), 936(\mathrm{w}), 806(\mathrm{~s}), 773(\mathrm{w}), 729(\mathrm{~s}), 695(\mathrm{~m})$, $674(\mathrm{w}), 611(\mathrm{~m}), 579(\mathrm{~m}), 536(\mathrm{~m}), 471(\mathrm{~s})$.

\section{Hydrogenation of $[\mathrm{RuH}(\mathrm{CO})(\mathrm{PNP})] 6$ to $\left[\mathrm{RuH}_{2}(\mathrm{CO})(\mathrm{HPNP})\right] 7$}

In a Young-Teflon capped NMR tube, $7 \mathrm{mg}(0.014 \mathrm{mmol})[\mathrm{RuH}-$ (CO)(PNP)] 6 were dissolved in $0.5 \mathrm{~mL}$ deuterated benzene. The content was pressurised with 1.5 bar $\mathrm{H}_{2}$ gas. After $10 \mathrm{~h}$, $79 \%$ conversion was detected via ${ }^{31} \mathrm{P}\left\{{ }^{1} \mathrm{H}\right\}-\mathrm{NMR}$. Only hydride signals are clearly visible.

${ }^{1} \mathrm{H}-\mathrm{NMR}:\left(300 \mathrm{MHz}\right.$, benzene- $\left.\mathrm{d}_{6}\right): \delta_{\mathrm{H}}[\mathrm{ppm}]=-5.86(\mathrm{t}, 1 \mathrm{H}$, $\left.{ }^{2} J_{\mathrm{PH}}=18.2 \mathrm{~Hz}, \mathrm{Ru}-\mathrm{H}\right),-6.13\left(\mathrm{t}, 1 \mathrm{H},{ }^{2} J_{\mathrm{PH}}=17.4 \mathrm{~Hz}, \mathrm{Ru}-\mathrm{H}\right)$. 
${ }^{31} \mathrm{P}\left\{{ }^{1} \mathrm{H}\right\}-\mathrm{NMR}:\left(121 \mathrm{MHz}\right.$, benzene-d $\left.\mathrm{d}_{6}\right): \delta_{\mathrm{P}}[\mathrm{ppm}]=110.1$ (s, 21\%, complex 6), 108.9 (s, 79\%, complex 7).

\section{Acknowledgements}

We acknowledge the Ministerium für Innovation, Wissenschaft und Forschung NRW (MIWF-NRW) for financial support within the Energy Research Program for the Scientist Returnee Award for M. H. G. Prechtl (NRW-Rückkehrerprogramm). For access to LIFDI-MS analysis, we gratefully acknowledge Prof. Dr T. Braun (Humboldt-University of Berlin, Germany). J.-H. Choi wants to thank Dr J. Neudörfl, T. Heidemann and A. Krest for helpful discussion. P. Kliesen is acknowledged for technical support for the XRD measurement.

\section{Notes and references}

1 M. Zhao, J. Li, Z. Song, R. Desmond, D. M. Tschaen, E. J. J. Grabowski and P. J. Reider, Tetrahedron Lett., 1998, 39, 5323-5326.

2 B. C. Holland and N. W. Gilman, Synth. Commun., 1974, 4, 203-210.

3 R. J. Gritter and T. J. Wallace, J. Org. Chem., 1959, 24, 10511056.

4 M. Zhao, J. Li, E. Mano, Z. Song, D. M. Tschaen, E. J. J. Grabowski and P. J. Reider, J. Org. Chem., 1999, 64, 2564-2566.

5 T. Mallat and A. Baiker, Chem. Rev., 2004, 104, 3037-3058.

6 G. Tojo, Oxidation of Primary Alcohols to Carboxylic Acids: A Guide to Current Common Practice (Basic Reactions in Organic Synthesis), Springer, 2010.

7 G.-J. t. Brink, I. W. C. E. Arends and R. A. Sheldon, Science, 2000, 287, 1636-1639.

8 A.-K. C. Schmidt and C. B. W. Stark, Org. Lett., 2011, 13, 4164-4167.

9 T. Zweifel, J.-V. Naubron and H. Grützmacher, Angew. Chem., Int. Ed., 2009, 121, 567-571.

10 S. Annen, T. Zweifel, F. Ricatto and H. Grützmacher, ChemCatChem, 2010, 2, 1286-1295.

11 E. Balaraman, E. Khaskin, G. Leitus and D. Milstein, Nat. Chem., 2013, 5, 122-125.

12 J. Zhang, M. Gandelman, L. J. W. Shimon, H. Rozenberg and D. Milstein, Organometallics, 2004, 23, 4026-4033.

13 J. Zhang, G. Leitus, Y. Ben-David and D. Milstein, J. Am. Chem. Soc., 2005, 127, 12429-12429.

14 C. Gunanathan, Y. Ben-David and D. Milstein, Science, 2007, 317, 790-792.

15 J. Zhang, M. Gandelman, L. J. W. Shimon and D. Milstein, Dalton Trans., 2007, 107-113.

16 R. E. Rodriguez-Lugo, M. Trincado, M. Vogt, F. Tewes, G. Santiso-Quinones and H. Grutzmacher, Nat. Chem., 2013, 5, 342-347.
17 E. Alberico, P. Sponholz, C. Cordes, M. Nielsen, H. J. Drexler, W. Baumann, H. Junge and M. Beller, Angew. Chem., Int. Ed., 2013, 52, 14162-14166.

18 M. Nielsen, E. Alberico, W. Baumann, H. J. Drexler, H. Junge, S. Gladiali and M. Beller, Nature, 2013, 495, 85-89.

19 L. E. Heim, N. E. Schloerer, J.-H. Choi and M. H. G. Prechtl, Nat. Commun., 2014, 5, 3621, DOI: 3610.1038/ncomms4621.

20 J.-H. Choi, N. E. Schloerer, J. Berger and M. H. G. Prechtl, Dalton Trans., 2014, 43, 290-299.

21 E. P. K. Olsen and R. Madsen, Chem. - Eur. J., 2012, 18, 16023-16029.

22 P. D. Bolton, M. Grellier, N. Vautravers, L. Vendier and S. Sabo-Etienne, Organometallics, 2008, 27, 5088-5093.

23 R. Çelenligil-Çetin, L. A. Watson, C. Guo, B. M. Foxman and O. V. Ozerov, Organometallics, 2005, 24, 186-189.

24 Y.-Z. Chen, W. C. Chan, C. P. Lau, H. S. Chu, H. L. Lee and G. Jia, Organometallics, 1997, 16, 1241-1246.

25 L. S. Van der Sluys, G. J. Kubas and K. G. Caulton, Organometallics, 1991, 10, 1033-1038.

26 B. Askevold, J. T. Nieto, S. Tussupbayev, M. Diefenbach, E. Herdtweck, M. C. Holthausen and S. Schneider, Nat. Chem., 2011, 3, 532-537.

27 Z. B. Han, L. C. Rong, J. Wu, L. Zhang, Z. Wang and K. L. Ding, Angew. Chem., Int. Ed., 2012, 51, 1304113045 .

28 B. N. Chaudret, D. J. Cole-Hamilton, R. S. Nohr and G. Wilkinson, J. Chem. Soc., Dalton Trans., 1977, 15461557.

29 T. M. Douglas and A. S. Weller, New J. Chem., 2008, 32, 966-969.

30 B. Rybtchinski, Y. Ben-David and D. Milstein, Organometallics, 1997, 16, 3786-3793.

31 B. L. Shaw and M. F. Uttley, J. Chem. Soc., Chem. Commun., 1974, 918-919.

32 H. Salem, L. J. W. Shimon, Y. Diskin-Posner, G. Leitus, Y. Ben-David and D. Milstein, Organometallics, 2009, 28, 4791-4806.

33 R. S. Paonessa and W. C. Trogler, J. Am. Chem. Soc., 1982, 104, 1138-1140.

34 M. Bertoli, A. Choualeb, A. J. Lough, B. Moore, D. Spasyuk and D. G. Gusev, Organometallics, 2011, 30, 34793482.

35 A. Friedrich, M. Drees, J. Schmedt auf der Günne and S. Schneider, J. Am. Chem. Soc., 2009, 131, 1755217553.

36 M. Kaess, A. Friedrich, M. Drees and S. Schneider, Angew. Chem., Int. Ed., 2009, 48, 905-907.

37 A. Friedrich, M. Drees, M. Käss, E. Herdtweck and S. Schneider, Inorg. Chem., 2010, 49, 5482-5494.

38 S. M. Kloek, D. M. Heinekey and K. I. Goldberg, Organometallics, 2006, 25, 3007-3011. 